\title{
An atypical case of HLA-B27-associated uveitis with hypopyon and posterior segment involvement
}

\section{BY THOMAS XIE, OD \& ETTY BITTON, OD, MSC, FAAO}

\begin{tabular}{|c|}
\hline ABSTRACT \\
\hline $\begin{array}{l}\text { The presence of a hypopyon and } \\
\text { posterior segment involvement } \\
\text { are uncommon clinical findings in } \\
\text { HLA-B27-associated uveitis. Further- } \\
\text { more, first-time attacks rarely occur in } \\
\text { the elderly. This report highlights an } \\
\text { atypical uveitis case involving an older } \\
\text { patient, an evident hypopyon and } \\
\text { severe intermediate uveitis in one eye. }\end{array}$ \\
\hline $\begin{array}{l}\text { The 60-year-old Caucasian male was } \\
\text { admitted for a painful, red eye with } \\
\text { a sudden decreased vision to hand } \\
\text { motion, in the affected eye. Ocular and } \\
\text { systemic history were unremarkable. } \\
\text { An anterior chamber examination of } \\
\text { the eye revealed extensive cells and } \\
\text { flare with a conspicuous hypopyon. An } \\
\text { evaluation of the posterior segment } \\
\text { revealed significant vitreous haze, } \\
\text { obstructing all view to the retina. } \\
\text { Despite the age and the atypical ocular } \\
\text { findings of the patient, a diagnosis of } \\
\text { HLA-B27-associated uveitis was made } \\
\text { following an extensive clinical and } \\
\text { laboratory evaluation. The inflammatory } \\
\text { condition was successfully managed } \\
\text { with a combination of intravenous, } \\
\text { topical and oral corticosteroids tapered } \\
\text { over the course of a few weeks, and } \\
\text { visual acuity recovered to 20/30. }\end{array}$ \\
\hline $\begin{array}{l}\text { This case is an important reminder } \\
\text { that atypical signs, such as a hypopyon } \\
\text { or intermediate uveitis, can occur } \\
\text { and may be a significant sign of } \\
\text { HLA-B27-associated uveitis. Clinicians } \\
\text { should be aware of the diverse } \\
\text { manifestations of HLA-B27-associated } \\
\text { uveitis and be careful to include a } \\
\text { comprehensive assessment of both the } \\
\text { anterior and posterior segments of any } \\
\text { presenting painful, red eye. }\end{array}$ \\
\hline $\begin{array}{l}\text { Keywords: anterior uveitis, intermediate } \\
\text { uveitis, HLA-B27, hypopyon }\end{array}$ \\
\hline
\end{tabular}

\section{Introduction} veitis, the most common form
of inflammatory eye disease, is an important public health concern. It accounts for a significant percentage (estimated at 10-15\%) of prevalent cases of legal blindness in the United States. ${ }^{1}$ The most frequent subtype is anterior uveitis, representing up to $92 \%$ of total cases in community-based ophthalmic practices. ${ }^{2}$ HLA (human leukocyte antigen)B27 positivity, a human major histocompatibility complex (MHC), is the most common identifiable cause of anterior uveitis and accounts for about $50 \%$ of the cases in different populations. ${ }^{3,4}$ HLA-B27-associated uveitis is characterized by recurrent alternating acute unilateral attacks of intraocular inflammation of the anterior segment of the eye, and typically affects young male adults. ${ }^{5}$ In uveitis related to HLA-B27, the presence of a hypopyon - a layer of white blood cells in the anterior chamber - and posterior segment involvement of the eye are uncommon.

A hypopyon suggests severe anterior segment intraocular inflammation and is a rare occurrence in patients with uveitis, occurring in less than $1 \%$ of all uveitis patients. ${ }^{6}$ Posterior segment involvement, namely intermediate and/or posterior uveitis, is also infrequent and has been reported in up to $25 \%$ of HLA-B27-associated uveitis cases. ${ }^{7-10}$ Furthermore, anterior and intermediate uveitis cases have a lower risk of hypopyon compared to patients with only anterior uveitis. ${ }^{6}$

This report highlights an atypical case of HLA-B27-associated uveitis that presented with both a hypopyon and severe intermediate uveitis in an elderly man.

\section{Case report}

A 60-year-old Caucasian male was seen in the eye clinic of a hospital reporting a red, painful right eye with decreased vision. The patient was in fact seen three days earlier for pain and inflammation from a right shoulder injury for which he was put on a narcotic analgesic (oxycodone $5 \mathrm{mg}$ and acetaminophen $325 \mathrm{mg}$ marketed as Percocet, one tablet every four hours as needed). The onset of his ocular symptoms coincided with the introduction of Percocet so he discontinued the drug after one day, however, his vision continued to worsen. Ocular history was unremarkable with no reports of trauma, surgery, inflammation or infection. Medication was limited to the recent use of Percocet for the shoulder and the occasional nonsteroidal anti-inflammatory drug (naproxen) for nonspecific pain in the body with no reported allergies to any medication. Review of all systems revealed episodes described as podagra (i.e. inflammation on the big toe related to episodes of gout) ${ }^{11}$ 
within the past year (although he was never officially diagnosed with gout) and a history of papular rashes on his forehead and both his shins with mild erythema and some excoriation (abraded areas where the skin is torn or worn off). Upon further questioning, the patient reported no history of ulcers, sores, irritable bowel disease, bloody stool, urination difficulties or shortness of breath. The patient's family history was unremarkable. The patient also denied excessive nicotine or alcohol use, and had not engaged in any sexual activity recently. The patient was oriented to time, place and person, and was lucid at the time of the examination.

Upon ocular examination, visual acuity (VA) was hand motion OD (without improvement with pinhole) and 20/30 OS. Slit lamp examination of the right eye revealed $2+$ injection of the bulbar conjunctiva. Fine keratic precipitates (KPs) were widely distributed throughout the cornea, although no corneal thinning was noted. Anterior chamber (AC) examination of the right eye revealed 4+ cells and flare (without convection current), fibrin production with a $1.5 \mathrm{~mm}$ hypopyon in the lower quadrant as seen in Figure 1. Dilated funduscopic examination (DFE) revealed severe vitreous haze (grade 4+ vitreous cells), obstructing all view to the retina. B-scan ultrasound revealed extensive vitreous debris. The left eye revealed only an early nuclear sclerotic cataract with no evidence of active or past inflammation. A summary of the ocular findings is shown in Table 1.

Given the B-scan, the patient was diagnosed with acute unilateral
Table 1: Clinical findings at initial presentation

\begin{tabular}{|l|l|l|}
\hline & RIGHT EYE (OD) & LEFT EYE (OS) \\
\hline Visual acuity & Hand motion & $20 / 30$ \\
\hline Pupil reactions & Normal & Normal \\
\hline Extraocular movements & Normal & Normal \\
\hline Tonometry (Tonopen) & $21 \mathrm{mmHg}$ & $22 \mathrm{mmHg}$ \\
\hline Bulbar conjunctiva & $2+$ injection & Unremarkable \\
\hline Cornea & Fine keratic precipitates widely distributed & \\
\hline Anterior chamber & $\begin{array}{l}4+\text { cells and flare, fibrin production with a 1.5 mm } \\
\text { high hypopyon, grade IV Van Herick angle }\end{array}$ & \\
\hline Crystalline lens & $\begin{array}{l}1+\text { nuclear sclerotic cataract without posterior } \\
\text { synechiae }\end{array}$ & $\begin{array}{l}\text { Severe vitreous haze (grade 4+ vitreous cell) with } \\
\text { extensive vitreous debris }\end{array}$ \\
\hline Posterior segment & & \\
\hline
\end{tabular}

nongranulomatous anterior and intermediate hypopyon uveitis, with a tentative HLA-B27 association. The patient received $125 \mathrm{mg}$ of intravenous anti-inflammatory glucocorticoid (methylprednisolone sodium succinate) coupled with a topical anti-inflammatory corticosteroid $(1 \%$ prednisolone acetate $q h$, with a loading dose before bedtime and upon awakening), a cycloplegic/ mydriatic agent (atropine 1\% tid), and an oral anti-inflammatory corticosteroid (prednisone $80 \mathrm{mg}$ daily). The patient was then sent to the laboratory to have his blood drawn for further analysis.

A subsequent review of his laboratory examination revealed an elevation of ESR, CRP and white blood cells. Laboratory results were positive for the following markers: HLA-B27, HSV IgG and HSV IgM. (SeeTable 2) The remainder of the work-up, including ACE, Toxoplasma, FTA-ABS, RPR and VZV titre, was negative. The etiology of the uveitis was thus confirmed as HLA-

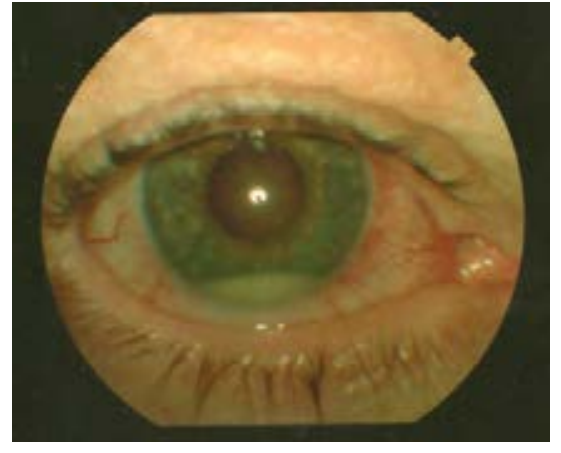

Figure 1 - $A$ bypopyon (beight of $1.5 \mathrm{~mm}$ ) seen at the lower quadrant of the anterior chamber

B27 positivity. The patient did not have a primary care provider, so a consultation with a rheumatologist was recommended.

The patient responded well to therapy. Ten days after treatment was initiated, VA of the right eye improved to $20 / 60$, IOP was $16 \mathrm{mmHg}$, anterior segment revealed few fine KPs inferiorly, 1+ cells and flare in the AC and a $<0.5 \mathrm{~mm}$ hypopyon. A DFE demonstrated $1+$ anterior vitreous cells, snowbanks and snowballs resting 
Table 2: Clinical laboratory results

\begin{tabular}{|c|c|c|c|}
\hline & PURPOSE & NORMAL VALUES & RESULT \\
\hline $\begin{array}{l}\text { Erythrocyte } \\
\text { Sedimentation Rate (ESR) }\end{array}$ & Inflammation & $\leq 30 \mathrm{~mm} / \mathrm{hr}$ & Elevated $(110 \mathrm{~mm} / \mathrm{hr})$ \\
\hline C-Reactive Protein (CRP) & Inflammation & $<6 \mathrm{mg} / \mathrm{L}$ & Elevated (19.35 mg/L) \\
\hline White blood cells & Inflammation & $\begin{array}{l}4 \times 10^{9} \text { to } \\
1.1 \times 10^{10} / \mathrm{L}\end{array}$ & $\begin{array}{l}\text { Mild leukocytosis } \\
\left(13.1 \times 10^{9} / \mathrm{L}\right)\end{array}$ \\
\hline $\begin{array}{l}\text { Human Leukocyte } \\
\text { Antigen B27 (HLA-B27) }\end{array}$ & $\begin{array}{l}\text { Specific protein } \\
\text { strongly associated with } \\
\text { spondyloarthropathies }\end{array}$ & Negative & Positive \\
\hline $\begin{array}{l}\text { Herpes Simplex Virus } \\
\text { (HSV) lgG }\end{array}$ & $\begin{array}{l}\text { Herpes simplex } \\
\text { virus-specific antibody }\end{array}$ & Negative & Positive \\
\hline $\begin{array}{l}\text { Herpes Simplex Virus } \\
\text { (HSV) IgM }\end{array}$ & $\begin{array}{l}\text { Herpes simplex } \\
\text { virus-specific antibody }\end{array}$ & Negative & Positive \\
\hline $\begin{array}{l}\text { Angiotensin-Converting } \\
\text { Enzyme (ACE) }\end{array}$ & Sarcoidosis & Negative & Negative \\
\hline Toxoplasma & Toxoplasmosis & Negative & Negative \\
\hline $\begin{array}{l}\text { Treponema Pallidum } \\
\text { Antibody (FTA-ABS) }\end{array}$ & Syphilis & Negative & Negative \\
\hline $\begin{array}{l}\text { Rapid Plasma Regain } \\
\text { (RPR) }\end{array}$ & Syphilis & Negative & Negative \\
\hline $\begin{array}{l}\text { Varicella-Zoster Virus } \\
\text { (VZV) titer }\end{array}$ & $\begin{array}{l}\text { Varicella zoster virus } \\
\text { antibodies }\end{array}$ & Negative & Negative \\
\hline
\end{tabular}

inferiorly. The macula, optic disc and the rest of the retina were unremarkable. Due to the marked subjective and objective improvement, tapering of oral prednisone was initiated $(60$ $\mathrm{mg}$ for 5 days, $40 \mathrm{mg}$ for 5 days, 30 $\mathrm{mg}$ for 5 days, $20 \mathrm{mg}$ for 5 days, 10 $\mathrm{mg}$ for 5 days, $5 \mathrm{mg}$ for 5 days, then discontinued).

At week 3, clinical evolution was favourable with VA at $20 / 30^{-2}$. The KPs and hypopyon disappeared (Figure 2), however grade $0.5+$ cells and flare remained in the AC, grade $0.5+$ cells in the anterior vitreous, and persistent snowbanks and snowballs. The left eye remained stable and quiet throughout the episode. At his last follow up at week nine, the patient had already discontinued both systemic and topical medication a week prior. His VA was maintained at $20 / 30^{-1}$, IOP was $16 \mathrm{mmHg}$,

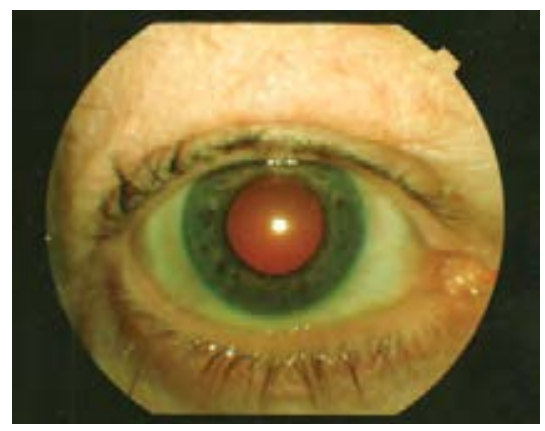

Figure 2: Anterior segment photo illustrating the resolved bypopyon and a clear anterior chamber

The patient was initially diagnosed with an acute nongranulomatous uveitis with a tentative HLA-B27 association, however, the hypopyon and intermediate uveitis were atypical. Ramsay and Lightman (2001) classified the causes of hypopyon into non-infectious causes, infectious agents, neoplasms, and corneal disorders. ${ }^{26}$ Table 4 shows the most common differential diagnosis for hypopyon, anterior uveitis and intermediate uveitis.

In both intraocular infection and inflammation, hypopyon consists largely of tissue debris, fibrin, inflammatory by-products and leukocytes, and signifies severe anterior segment intraocular inflammation. ${ }^{6}$ A study by Zaidi et al, ${ }^{6}$ indicates that hypopyon is an uncommon finding in patients with uveitis, occurring in around 8.57 patients per 1000 person-years $(0.86 \%)$, even in tertiary uveitis practices. This retrospective study indicated that hypopyon was more common among patients with uveitis limited to the anterior chamber than in patients who also had intermediate uveitis as a part of their diagnosis, but was nearly 
Table 3: Possible etiologies for uveitis

\begin{tabular}{|c|c|c|}
\hline & GENERAL DESCRIPTION & OCULAR MANIFESTATIONS \\
\hline HLA-B27 positivity ${ }^{5}$ & $\begin{array}{l}\text { Genetic marker associated with spondyloarthropathies } \\
\text { Most common identifiable cause of anterior uveitis (50\%) }\end{array}$ & Anterior uveitis \\
\hline $\begin{array}{l}\text { Herpes simplex } \\
\text { uveitis }^{12,13,35-38}\end{array}$ & $\begin{array}{l}\text { Uveitis caused by Herpes simplex virus } \\
\text { Secondary to herpetic keratitis } \\
\text { Absence of corneal disease in } 15 \%\end{array}$ & $\begin{array}{l}\text { Corneal scarring } \\
\text { Unilateral recurrent anterior uveitis } \\
\text { Iris atrophy, elevated IOP, KPs and synechiae } \\
\text { Hypopyon possible } \\
\text { Posterior segment inflammation in 15\% }\end{array}$ \\
\hline Behçet's disease ${ }^{14}$ & $\begin{array}{l}\text { Systemic vasculitis disorder of unknown etiology } \\
\text { Relapsing episodes of oral ulcers, genital ulcers and skin lesions }\end{array}$ & Sudden attacks of anterior uveitis with hypopyon \\
\hline Sarcoidosis $15,16,17$ & $\begin{array}{l}\text { Chronic non-caseating granulomatous systemic disease of } \\
\text { unknown etiology } \\
\text { A third of patients have ocular involvement }\end{array}$ & $\begin{array}{l}\text { Chronic bilateral anterior uveitis } \\
\text { Iris nodules, posterior synechiae, KPs and peripheral } \\
\text { anterior synechiae } \\
\text { Posterior segment involvement possible }\end{array}$ \\
\hline Toxoplasmosis $2,18,19$ & $\begin{array}{l}\text { Infection caused by the parasite Toxoplasma gondii } \\
\text { Most common infectious cause of intraocular inflammation in } \\
\text { immunocompetent patients }\end{array}$ & Can cause anterior uveitis and retinal vasculitis \\
\hline $\begin{array}{l}\text { Herpes zoster } \\
\text { ophthalmicus } \\
\text { (ocular shingles) }^{20}\end{array}$ & $\begin{array}{l}\text { Reactivation of the Varicella-zoster virus } \\
50 \% \text { develop ocular complications, with uveitis occurring in } 43 \%\end{array}$ & $\begin{array}{l}\text { High incidence of secondary glaucoma } \\
\text { Uveitis is uniphasic and short-lived }\end{array}$ \\
\hline Syphilis ${ }^{21-24}$ & $\begin{array}{l}\text { Sexually-transmitted infectious disease by Treponema pallidum } \\
\text { Many people do not have symptoms } \\
\text { Can initially present as anterior uveitis }\end{array}$ & $\begin{array}{l}\text { Can mimic many ocular conditions } \\
\text { Uveitis can be unilateral or bilateral, acute or chronic } \\
\text { Can cause hypopyon }\end{array}$ \\
\hline Tuberculous uveitis ${ }^{25}$ & $\begin{array}{l}\text { Rare } \\
\text { Caused by Mycobacterium tuberculosis } \\
2 \% \text { of active tuberculosis }\end{array}$ & $\begin{array}{l}\text { Chronic granulomatous anterior uveitis } \\
\text { Disseminated choroiditis with vitritis } \\
\text { Cystoid macular oedema }\end{array}$ \\
\hline
\end{tabular}

as frequent among patients with posterior or panuveitis. The most common risk factors for hypopyon are Behçet's disease and HLA-B27 positivity, conferring respectively an approximate five-fold and two-fold increased risk of hypopyon. In fact, HLA-B27 hypopyon uveitis occurs in $5.7 \%$ of all uveitis cases and is more common among Caucasians. ${ }^{27}$ Even though hypopyon is an indicator of remarkably severe inflammation, eyes that develop hypopyon do not appear to have adverse visual outcomes more often than eyes without it. A previous study on Behçet's disease showed that patients who developed hypopyon were more likely to gain three lines of vision at any point during follow-up, probably because the haze associated with a hypopyon was a reversible cause of vision loss. ${ }^{28}$

Intermediate uveitis is diagnosed when intraocular inflammation primarily involves the vitreous, peripheral retina and pars plana ciliaris. ${ }^{29}$ It is the type of uveitis with the longest clinical duration. ${ }^{30}$ The syndrome is more frequent in the third and fourth decade. ${ }^{31}$ Intermediate uveitis has been reported to make up $1.4-22 \%$ of all uveitis cases. ${ }^{32}$ Although the majority of cases are of unknown etiology, a significant association between intermediate uveitis and multiple sclerosis, sarcoidosis and Lyme disease has been reported. ${ }^{33,34}$ Intermediate uveitis is bilateral $80 \%$ of the time. Main clinical features are vitreous cells, with or without snowballs and snow banking. The intermediate uveitis found in this case was atypical in that it was monocular and not associated with the aforementioned diseases.

In the case reported here, the patient's laboratory results were positive for HLA-B27, HSV IgG and HSV IgM, which pointed towards an etiology of either an HLA-B27associated uveitis or Herpes simplex uveitis.

Acute HSV uveitis is typically secondary to herpetic keratitis, although $15 \%$ of patients may not experience corneal involvement. ${ }^{35,39}$ Clinical signs of HSV uveitis include corneal scarring, focal or patchy iris atrophy, iris transillumination defects, $\mathrm{KP}$, 
Table 4: Most common differential diagnosis of hypopyon, anterior uveitis and intermediate uveitis

\begin{tabular}{|l|l|l|}
\hline \multicolumn{1}{|c|}{ HYPOPYON } & \multicolumn{1}{|c|}{ ANTERIOR UVEITIS } & \multicolumn{1}{c|}{ INTERMEDIATE UVEITIS } \\
\hline Non-infectious & Idiopathic & Idiopathic \\
HLA-B27 & MLA-B27 & Multiple sclerosis \\
Behçet's disease & Sarcoidosis \\
Spondyloarthropathy & Reactive arthritis (Reiter's syndrome) & Lyme disease \\
latrogenic/Neoplasm/Trauma & Ankylosing spondylitis & \\
Infectious & Sarcoidosis & \\
Endogenous endophthalmitis & Syphilis & \\
Toxoplasmosis & HSV & \\
Syphilis & Trauma & \\
Hansen's disease & Posner-Schlossman Syndrome \\
Brucellosis & Neoplasm \\
HSV & Lymphoma, leukemia, retinoblastoma & \\
Keratitis & Other & \\
Other & \multicolumn{1}{|c|}{} \\
\hline
\end{tabular}

posterior synechiae, and elevated IOP. ${ }^{39-41}$ A unilateral anterior uveitis coupled with an elevated IOP point to HSV uveitis. The presence of patchy iris atrophy and transillumination defects corroborates the diagnosis. Since the clinical presentation of this case did not involve the iris or an elevated IOP, HSV uveitis was rejected as a potential diagnosis and HLA-B27 positivity was favoured as the main etiology.

Despite the atypical presentation, the prognosis was positive for this patient, like in most HLA-B27associated uveitides. With only topical and systemic steroids, the clinical progression was favourable and the patient regained VA to $20 / 30^{-1}$ within 9 weeks. The patient suffered from inflammation of his right shoulder just before the onset of his uveitis attack. It is unclear at this time whether the shoulder inflammation and the uveitis are two separate inflammatory events, or whether they are part of a single systemic problem. HLA-B27associated anterior uveitis patients with concomitant posterior segment manifestations have a significantly higher incidence of associated systemic diseases, namely ankylosing spondylitis, inflammatory bowel diseases or reactive arthritis (formerly referred to as Reiter's syndrome). ${ }^{42}$ Thus, a referral to rheumatology was recommended to rule these out. The patient has been educated that recurrences are highly possible, and that this process may be part of a systemic inflammatory condition, which may require steroids and/or chronic immunosuppressive therapy. However, the patient was not seen in a follow-up after the referral.

\section{HLA-B27-associated uveitis}

As the most common specific uveitis diagnosis, HLA-B27associated uveitis accounts for approximately $13-17 \%$ of all uveitis cases. ${ }^{2,43}$ About $50 \%$ of patients suffering from acute anterior uveitis are HLA-B27 positive. ${ }^{5}$ HLA-B27-associated uveitis is three times more common in males. ${ }^{44}$ The average age of onset of the disease is 35 , although cases have been reported in children $(10 \%$ of cases begin prior to 20 years old) and late adulthood (5\% after 55 years of age). ${ }^{10}$
The classic presentation of HLA-B27-associated ocular disease is acute anterior uveitis (AAU)..$^{10}$ The onset is typically abrupt and symptoms include photophobia, ocular pain, epiphoria, ocular redness, and mild-to-severe visual blurring. Cases are generally unilateral but a recurrent attack may affect the contralateral eye. Although the inflammation is usually nongranulomatous, it may be severe enough to cause a hypopyon or a plasmoid aqueous.

HLA-B27-associated AAU is in fact the most common cause of hypopyon uveitis in North America. ${ }^{27}$ Uncommon cases (less than 25.1\%) cases may involve the posterior segment. ${ }^{7}$ Such posterior segment involvement is recognized as vitritis, cystoid macular oedema, papillitis and retinal vasculitis, and is thought to be secondary to anterior segment inflammation. ${ }^{10,45}$ Thus, HLA-B27associated uveitis may be unusually severe and may cause a panuveitis, which is an under-recognized phenomenon. ${ }^{46}$ During an acute attack, IOP is generally lowered due to the shutdown of the ciliary body. Nevertheless, increased IOP and secondary glaucoma is a 
well-recognized complication due to iris bombé or synechial angle closure. Uveitis attacks are normally short-lived and resolve within three months. Recurrent episodes are common, but the frequency varies between multiple attacks per year to single attacks separated by one or more decades. ${ }^{46}$

There is a stepladder approach to the management of uveitis. ${ }^{47}$ The immediate goal is to control the inflammation and ciliary spasm, with a long-term goal of addressing the underlying cause of the uveitis. First-time occurrences and uncomplicated recurrences can be treated with topical corticosteroid, such as prednisolone acetate $1 \%$, which has a moderate potency and is appropriate for many cases. Although the risk of systemic side effects is low, $1 \%$ of patients experience increased IOP, in which case a milder formulation such as rimexolone and lotoprednol can be utilized. ${ }^{48}$ The concomitant use of a cycloplegic/mydriatic drop, such as atropine sulphate $1 \%$, reduces pain from ciliary spasm and may break or prevent posterior synechiae.

More severe cases may require a combination of oral, topical, periocular or intravitreal treatments. Systemic corticosteroid administration is required in $24 \%$ of patients. A typical oral starting dose is $1 \mathrm{mg} / \mathrm{kg}$ of prednisone daily. Side effects resulting from a short course of systemic steroids are infrequent but include sleep disturbances, weight gain, increased appetite, mood imbalance and more. ${ }^{49}$ In extreme cases of uveitis involving the posterior segment, periocular or intravitreal corticosteroids may be considered..$^{50}$
Periocular injections (transseptally, in the sub-tenon's space or subconjunctivally) are designed as depot injections (e.g. triamcinolone acetate) and therefore, are effective for an extended period of time. ${ }^{51}$ Intravitreal injections are effective for three to six months, minimize systemic side effects, and have the benefit of treating macular oedema caused by posterior uveitis. ${ }^{52}$ On the other hand, ocular complications (e.g. cataracts and increased IOP) are more common with intravitreal injections than with systemic steroids.

Extreme sight-threatening cases may require pulse intravenous (IV) steroids to bring the inflammation under control more quickly and to prevent irreparable damage. The recommended regimen for such cases is methylprednisolone $1 \mathrm{~g} \mathrm{IV}$ per day for 3 days, with subsequent transition to oral therapy, starting at $1 \mathrm{mg} / \mathrm{kg}$ per day. ${ }^{47,53,54}$ For recalcitrant cases, steroid-free strategies can be considered, such as oral NSAID therapy or immunosuppressive therapy. ${ }^{55,56,47}$

Patients on topical or systemic steroids for an extended period of time (i.e. over two weeks) should be tapered off over the course of several weeks to avoid rebound inflammation after topical use, or inducing adrenal crisis from abrupt stoppage of oral corticosteroid use. Patients requiring immunosuppressive therapy should remain on their regimen without dose reductions to prevent any recurrences, which may be difficult to control.

HLA-B27 testing in patients with uveitis is useful because it may help to identify a previously undiagnosed systemic disease. Among patients with HLA-B27-associated uveitis, around $70 \%$ will have an associated (rheumatoid factor) seronegative spondyloarthropathy of which approximately $50 \%$ will not have been diagnosed or will have been misdiagnosed. Seronegative spondyloarthropathy includes ankylosing spondylitis, reactive arthritis (Reiter's syndrome), psoriatic arthropathy, and arthritis associated with inflammatory bowel disease. Patients with posterior segment manifestations have a significantly higher incidence of such systemic diseases. ${ }^{42,57}$ In addition, around $30-90 \%$ of patients with HLA-B27-associated uveitis suffer from associated joint disease. ${ }^{58}$ As a result, HLA-B27 testing can be beneficial in improving management of the patient's overall systemic health.

\section{Summary}

In this case report, a final diagnosis of HLA-B27-associated uveitis was made following an extensive clinical and laboratory evaluation despite the atypical presentation. The hypopyon and its associated anterior and intermediate uveitis were successfully treated with topical and systemic steroids. This case is an important reminder that, although uncommon, hypopyon and posterior segment involvement may be present in an HLA-B27-associated uveitis, and can even affect the elderly. Furthermore, it is important to include a comprehensive assessment of both the anterior and posterior segments of any presenting painful, red eye for a full clinical appreciation. 


\section{Acknowledgement}

We would like to thank Gerald

Abruziese, OD from the Syracuse

Veterans Affairs Medical Center for his

belp and guidance.

This paper was presented in part, as as poster at the American Academy of Optometry's Annual meeting in Boston on October 14, 2011.

\section{References}

1. Rothova A, Suttorp-van Schulten MS, Frits Treffers W, Kijlstra A. Causes and frequency of blindness in patients with intraocular inflammatory disease. Br J Ophthalmol 1996;80(4):332-6.

2. McCannel CA, Holland GN, Helm CJ, et al. Causes of uveitis in the general practice of ophthalmology. UCLA Community-Based Uveitis Study Group. Am J Ophthalmol 1996;121(1):35-46.

3. Brewerton DA, Caffrey M, Nicholls A, et al. Acute anterior uveitis and HL-A 27. Lancet 1973;302(7836):994-6.

4. Feltkamp TE. Ophthalmological significance of HLA associated uveitis. Eye (Lond) 1990;4 ( Pt 6):839-44.

5. Wakefield D, Chang JH, Amjadi S, et al. What is new HLA-B27 acute anterior uveitis? Ocul Immunol Inflamm 2011;19(2):139-44.

6. Zaidi AA, Ying GS, Daniel E, et al. Hypopyon in patients with uveitis. Ophthalmology 2010;117(2):366-72.

7. Kase S, Namba K, Horie Y, et al. Repeated exacerbations of ocular inflammation with vitreous hemorrhage in a patient with HLA-B27 associated uveitis. J Med Invest 2007;54(3-4):350-3.

8. Dodds EM, Lowder CY, Meisler DM. Posterior segment inflammation in HLA-B27+ acute anterior uveitis: clinical characteristics. Ocul Immunol Inflamm 1999;7(2):85-92.

9. Rothova A. Comment on 'Posterior segment inflammation in HLA-B27+ acute anterior uveitis: clinical characteristics'. Ocul Immunol Inflamm 2000;8(1):73-5.

10. Tay-Kearney ML, Schwam BL, Lowder $\mathrm{C}$, et al. Clinical features and associated systemic diseases of HLA-B27 uveitis. Am J Ophthalmol 1996;121(1):47-56.

11. Schumacher HR, Jr. The pathogenesis of gout. Cleve Clin J Med 2008;75 Suppl $5: S 2-4$.

12. Dawson CR, Togni B. Herpes simplex eye infections: clinical manifestations, pathogenesis and management. Surv Ophthalmol 1976;21(2):121-35.

13. Santos C. Herpes simplex uveitis. Bol Asoc Med P R 2004;96(2):71-4, 7-83.

14. Mendes D, Correia M, Barbedo M, et al. Behcet's disease--a contemporary review. J Autoimmun 2009;32(3-4):178-88.

15. Cozier YC, Berman JS, Palmer JR, et al. Sarcoidosis in black women in the United States: data from the Black Women's Health Study. Chest 2011;139(1):144-50.

16. Uyama M. Uveitis in sarcoidosis. Int Ophthalmol Clin 2002;42(1):143-50.

17. Jones NP. Sarcoidosis and uveitis. Ophthalmol Clin North Am 2002;15(3):319-26, vi.

18. Park YH, Han JH, Nam HW. Clinical features of ocular toxoplasmosis in Korean patients. Korean J Parasitol 2011;49(2):167-71.

19. Bornand JE, de Gottrau P. Uveitis: is ocular toxoplasmosis only a clinical diagnosis? Ophthalmologica 1997;211(2):87-9.

20. Thean JH, Hall AJ, Stawell RJ. Uveitis in Herpes zoster ophthalmicus. Clin Experiment Ophthalmol 2001;29(6):40610.

21. Hong MC, Sheu SJ, Wu TT, Chuang CT. Ocular uveitis as the initial presentation of syphilis. J Chin Med Assoc 2007;70(7):274-80.

22. Reddy S, Cubillan LD, Hovakimyan A, Cunningham ET, Jr. Inflammatory ocular hypertension syndrome (IOHS) in patients with syphilitic uveitis. Br J Ophthalmol 2007;91(12):1610-2.
23. Tucker JD, Li JZ, Robbins GK, et al. Ocular syphilis among HIV-infected patients: a systematic analysis of the literature. Sex Transm Infect 2011;87(1):4-8.

24. Lutchman C, Weisbrod DJ, Schwartz CE. Diagnosis and management of syphilis after unique ocular presentation. Can Fam Physician 2011;57(8):896-9.

25. Varma D, Anand S, Reddy AR, et al. Tuberculosis: an under-diagnosed etiological agent in uveitis with an effective treatment. Eye (Lond) 2006;20(9):1068-73.

26. Ramsay A, Lightman S. Hypopyon uveitis. Surv Ophthalmol 2001;46(1):1-18.

27. D’Alessandro LP, Forster DJ, Rao NA. Anterior uveitis and hypopyon. Am J Ophthalmol 1991;112(3):317-21.

28. Nussenblatt RB. Uveitis in Behcet's disease. Int Rev Immunol 1997;14(1): 67-79.

29. Jabs DA, Nussenblatt RB, Rosenbaum JT. Standardization of uveitis nomenclature for reporting clinical data. Results of the First International Workshop. Am J Ophthalmol 2005;140(3):509-16.

30. Bloch-Michel E. Opening address: intermediate uveitis. Dev Ophthalmol 1992;23:1-2.

31. Chan SM, Hudson M, Weis E. Anterior and intermediate uveitis cases referred to a tertiary centre in Alberta. Can J Ophthalmol 2007;42(6):860-4.

32. Babu BM, Rathinam SR. Intermediate uveitis. Indian J Ophthalmol 2010;58(1):21-7.

33. Zierhut M, Foster CS. Multiple sclerosis, sarcoidosis and other diseases in patients with pars planitis. Dev Ophthalmol 1992;23:41-7.

34. Breeveld J, Rothova A, Kuiper H. Intermediate uveitis and Lyme borreliosis. Br J Ophthalmol 1992;76(3):181-2.

35. Miserocchi E, Waheed NK, Dios E, et al. Visual outcome in herpes simplex virus and varicella zoster virus uveitis: a clinical evaluation and comparison. Ophthalmology 2002;109(8):1532-7. 
36. Liesegang TJ. Ocular herpes simplex infection: pathogenesis and current therapy. Mayo Clin Proc 1988;63(11):1092-105.

37 Schacher S, Garweg JG, Russ C, Bohnke M. Diagnosis of herpetic uveitis and keratouveitis]. Klin Monbl Augenheilkd 1998;212(5):359-62.

38. Rodriguez A, Power WJ, Neves RA, Foster CS. Recurrence rate of herpetic uveitis in patients on longterm oral acyclovir. Doc Ophthalmol 1995;90(4):331-40.

39. Liesegang TJ. Herpes simplex virus epidemiology and ocular importance Cornea 2001;20(1):1-13.

40. Kaye S, Choudhary A. Herpes simplex keratitis. Prog Retin Eye Res 2006;25(4):355-80.

41. Liesegang TJ Classification of herpes simplex virus keratitis and anterior uveitis. Cornea 1999;18(2):127-43.

42. Kataria RK, Brent LH. Spondyloarthropathies. Am Fam Physician 2004;69(12):2853-60.

43. Rodriguez A, Calonge M, PedrozaSeres M, et al. Referral patterns of uveitis in a tertiary eye care center. Arch Ophthalmol 1996;114(5):593-9.

44. Power WJ, Rodriguez A, PedrozaSeres M, Foster CS. Outcomes in anterior uveitis associated with the
HLA-B27 haplotype Ophthalmology 1998;105(9): $1646-51$

45. Rodriguez A, Akova YA, Pedroza-Seres M, Foster CS. Posterior segment ocular manifestations in patients with HLAB27-associated uveitis. Ophthalmology 1994;101(7):1267-74.

46. Smith JR. HLA-B27--associated uvertis. Ophthalmol Clin North Am 2002; 15(3):297-307.

47. Lee PF, Foster CS. Pharmacotherapy of uveitis. Expert Opin Pharmacother 2010;11(7):1135-46.

48. Tripathi RC, Parapuram SK, Tripathi BJ, et al. Corticosteroids and glaucoma risk. Drugs Aging 1999;15(6):439-50.

49. Noone T. An overview of steroid use and its potential side-effects. Nurs Times 2006;102(17):24-7.

50. Ferrante P, Ramsey A, Bunce C, Lightman S. Clinical trial to compare efficacy and side-effects of injection of posterior sub-Tenon triamcinolone versus orbital floor methylprednisolone in the management of posterior uveitis. Clin Experiment Ophthalmol 2004;32(6):563-8.

51. Riordan-Eva P, Lightman S. Orbital floor steroid injections in the treatment of uveitis. Eye (Lond) 1994;8 ( Pt 1): 66-9.
52. Antcliff RJ, Spalton DJ, Stanford $\mathrm{MR}$, et al. Intravitreal triamcinolone for uveitic cystoid macular edema: an optical coherence tomography study. Ophthalmology 2001;108(4):765-72.

53. Yalcindag FN, Can E, Ozdemir O. Intravenous methylprednisolone pulse therapy for acute posterior segment uveitis attacks in Behcet's disease. Ann Ophthalmol (Skokie) 2007;39(3):194-7.

54. Wakefield D, McCluskey P, Penny R. Intravenous pulse methylprednisolone therapy in severe inflammatory eye disease. Arch Ophthalmol 1986;104(6):847-51.

55. Okada AA. Immunomodulatory therapy for ocular inflammatory disease: a basic manual and review of the literature. Ocul Immunol Inflamm 2005;13(5):33551.

56. Bom S, Zamiri P, Lightman S. Use of methotrexate in the management of sight-threatening uveitis. Ocul Immunol Inflamm 2001;9(1):35-40.

57. Monnet D, Breban M, Hudry C, et al Ophthalmic findings and frequency of extraocular manifestations in patients with HLA-B27 uveitis: a study of 175 cases. Ophthalmology 2004;111(4): 802-9.

58. Rosenbaum JT. Acute anterior uveitis and spondyloarthropathies. Rheum Dis Clin North Am 1992;18(1): 143-51.

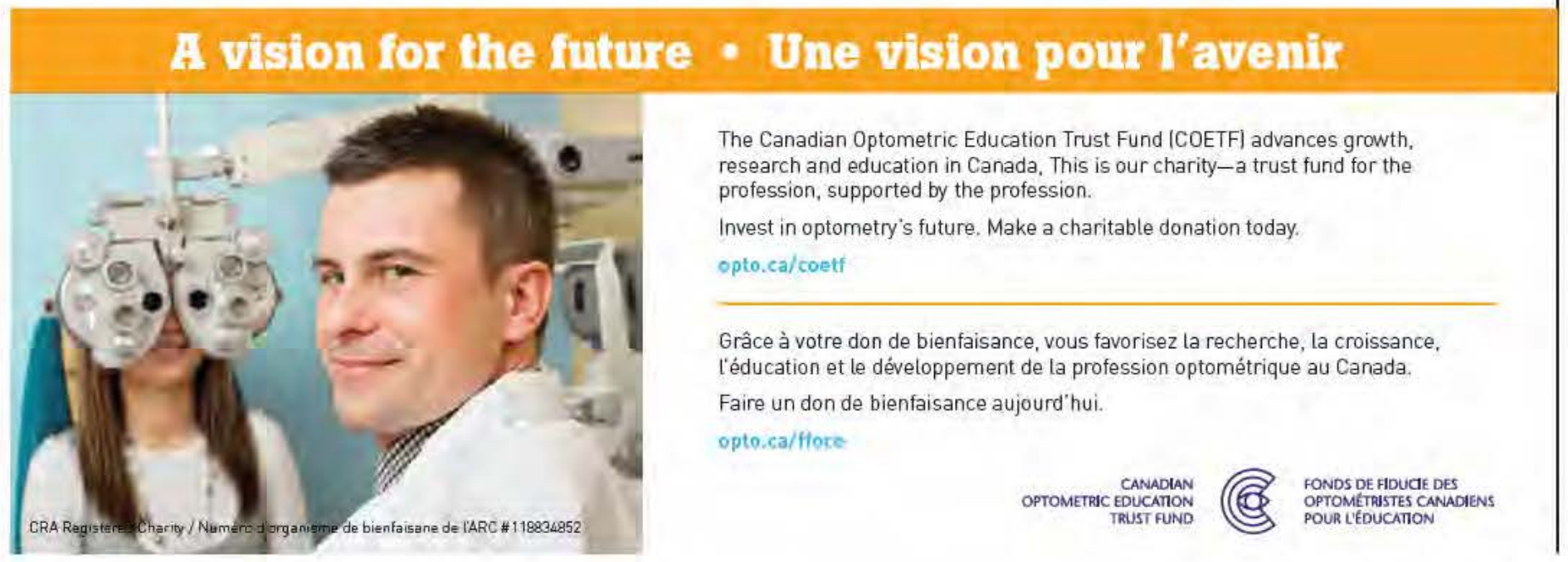

